\title{
Enhancing students' learning motivation through bibliocounseling technique
}

\author{
Eva Kartika Wulan Sari ${ }^{*} 1$ \\ ${ }^{1}$ Universitas Kanjuruhan Malang, Indonesia \\ ${ }^{*}$ Corresponding author, Đe-mail: evakartikawulansari@unikama.ac.id
}

\begin{abstract}
This study aimed at enhancing students' learning motivation using bibliocounseling technique. The research subjects comprises of 11th grade students of a Senior High School (SMA) selected through purposive random sampling. The instrument of the study consisted of learning motivation scale and observation guide with a pretest and posttest design technique. Data were examined using descriptive analysis and Wilcoxon test. The result of the study therefore showed a difference between the pre-test and post-test scores, with a $37 \%$ increase from the intermediate to high category. Furthermore, the result of statistical analysis on Wilcoxon test exhibited differences in students' motivation through bibliocounseling. Therefore, it could be concluded that bibliocounseling technique enhances students' learning motivation.
\end{abstract}

Keywords: Bibliocounseling, learning motivation

How to Cite: Sari, E. K. W. (2019). Enhancing students' learning motivation through bibliocounseling technique. COUNS-EDU: The International Journal of Counseling and Education, 4(1), 23-28. doi:https://dx.doi.org/10.23916/0020190419410

This is an open access article distributed under the Creative Commons Attribution License, which permits unrestricted use, distribution, and reproduction in any medium, provided the original work is properly cited. (C2019 by author.

\section{Introduction}

National Education aims to develop students to be a healthy, knowledgeable, competent, creative, independent, democratic, and responsible individuals with noble characters and who believe in God (Undang-Undang No. 20, 2003). Based on the stipulation, it is evident that its purpose is to ascertain ad enhance the children's characters across the nation. Every student possesses stimulus and impulse known as motivation, which they use to carry out learning activity at school (Su \& Cheng, 2015). (Hester \& Gore, 2015).

Motivation refers to fundamental encouragement used to carry out an activitiesin accordance with an individual(Baumeister, 2016; Nicoll, 2014; Sarkar, 2019; Veilleux, 2019; Zeigler-Hill, Vrabel, Sauls, \& Lehtman, 2019). Presently, teachers often face obstacles while teaching, for example, students tend to be bored during the learning process due to poor educational strategies which do not encourage them (Kennedy, 2016). This also makes students less active during the learning process, especially on difficult subjects (Freeman et al., 2014; Liu \& Chiang, 2019).

According to Brophy, 2017, majority of high school students are not motivated to to enhance their learning skill (Wolff, Wagner, Poznanski, Schiller, \& Santen, 2015). Davis, Wilcoxon, \& Townsend, 2017 stated bibliocounseling as one of the techniques used in improving learning abilities. In general, bibliocounseling and counseling share the same purpose, to assist students in obtaining the right learning motivation (Pardeck, 2014). It aims to solve problems associated with counselee (Csorba-Simon, 2014; lbay, 2016; N Karacan \& Güneri, 2010; Özdemir, 2016). Therefore, the purpose of bibliocounseling is highly dependent on the counselee's problem, and ability to overcome these complications (Akinola, 2014). 
Some of the obstacles associated with bibliocounseling are unfamiliarity with effective learning method, difficulty eliminatebashfulness, inability to be assertive, lack of confidence, smoking and addiction to alcohol (Pardeck, 2014). In this current study, the steps associated with bibliocounseling are as follows (Nurten Karacan \& Güneri, 2010): (1) Motivation, counselor may provide introductory activity such as role-playing which is able to motivate counselee to be actively involved in the activity, (2) adequate time should be given to the counselee to read through educational materials provided by the counselor. (3) the researcher or counselor gives the student ample time to contemplate and reflect on the material, (4) Follow up through discussions, which enables the counselee to share new and existing ideas (5)

Bibliocounseling which utilizies information or knowledge from literature is expected to be media therapeutical, especially for students with low-learning motivation (Canty, 2017). It is considered a suitable technique in enhancing students' learning motivation (Furner, 2017). The use of books as an alternative learning method can be in the form of a storybook, article, newspaper, poem, magazine, novel, motivating video, etc. (Gerlach \& Subramanian, 2016). This method is highly recommended, especially for those who find it difficult to express their problem verbally (Béres, 2015).

Through bibliocounseling, students become more active, with positive mindset, objective to their experiences, and open-minded in order to obtain adequate insight based on their reading material (Altunbay, 2018). Based on the previously described, the researcher attempts to enhance students learning motivation using this technique.

\section{Method}

The present research was a pre-experimental study (Creswell \& Creswell, 2017) which made use of the One-group pretest-posttest design technique (Nardi, 2018). Before administering any treatment, the subjects were asked to work on the pre-test, and at the end, students were advised to utilize the post-test. This study uses two variables namely, Bibliocounseling (Independent) and Learning Motivation (Dependent). Eight SMA students with low-learning motivation were selected using the purposive sample technique. The instrument consists of learning motivation scale and observation guide with data examined using descriptive analysis and Wilcoxon test.

\section{Results and Discussions}

In addition, the use of bibliocounseling in this study is also based on Meier-Jensen principle (MeierJensen, 2001) which stated that there are five steps in conducting bibliocounseling namely preparation, book introduction, reading, discussion, and follow up activity. Counselors are also advised to determine the behavior target for their students (Shem, 2016). Books should be chosen based on the target behavior and in line with the counselee's developmental stage (Gupta, Mishra, \& Saini, 2017).

This study therefore aims to enhance students' learning motivation through group counseling using bibliocounseling technique which was implemented using short stories with the first entitled "kesulitan pita." Using these stories, students were expected to possess an understanding of eagerness and willingness to study with the ability to carry out the following; (1) explain the source of motivation in order to complete the assignment successfully, (2) explain the methods used in obtaining perfect learning outcome.

The second was titled "motivasi yang kuat." By using this story, the students were expected to possess courage and needs during learning. The indicators were; 1 ) they are able to mention how to avoid learning failure, (2) ability to mention the external source used to support the education.

The third story was entitled "menggapai cita-cita." Through this story, students were expected to be able to explain their hope and ideals with respect to learning. The indicators were students (1) ability to express their belief or perceived action, (2) capability to explain the purpose/result they want to obtain based on the belief or perceived action in learning. The fourth was titled "rajin membaca." Through this, students are expected to be rewarded for their learning activity. The fifth was entitled "kemandirian hidupku." Through this story, students were expected to give advice in ways to develop exciting learning activities while providing support (stimulus) to the learning process. The last short story was "ember yang 
bocor." Through this story, the students were expected to have an understanding of conducive learning environment with their ability to explain how. it affects them.

In this study, the treatments/group counseling services with bibliocounseling technique were given to eight meeting groups. The result of the first meeting (pre-test) showed that the subjects of the study possessed learning motivation categorized as low. They were KRR, FM, ANA, MREW, RAA, RI, YA, MRF. The result of the pre-test showed that KRR, FM, ANA, MREW, RAA, RI, YA, MRF's score for learning motivation were $83,83,82,84,81,83,84$, and 83 respectively.

Their learning motivation was categorized as low, owing to the difficulties experienced during the learning process. Based on the result, the researcher treats each with group counseling and bibliocounseling technique in order to enhance their learning motivation.

After the treatments were conducted, there was an improvement in students motivation level. The result of the post-test showed that KRR, FM, ANA, MREW, RAA, RI, YA, MRF's score for learning motivation were $131,134,138,129,128,136,129$, and 128 respectively. The comparison between pretest and posttest result of the subjects is shown in chart 1 below:

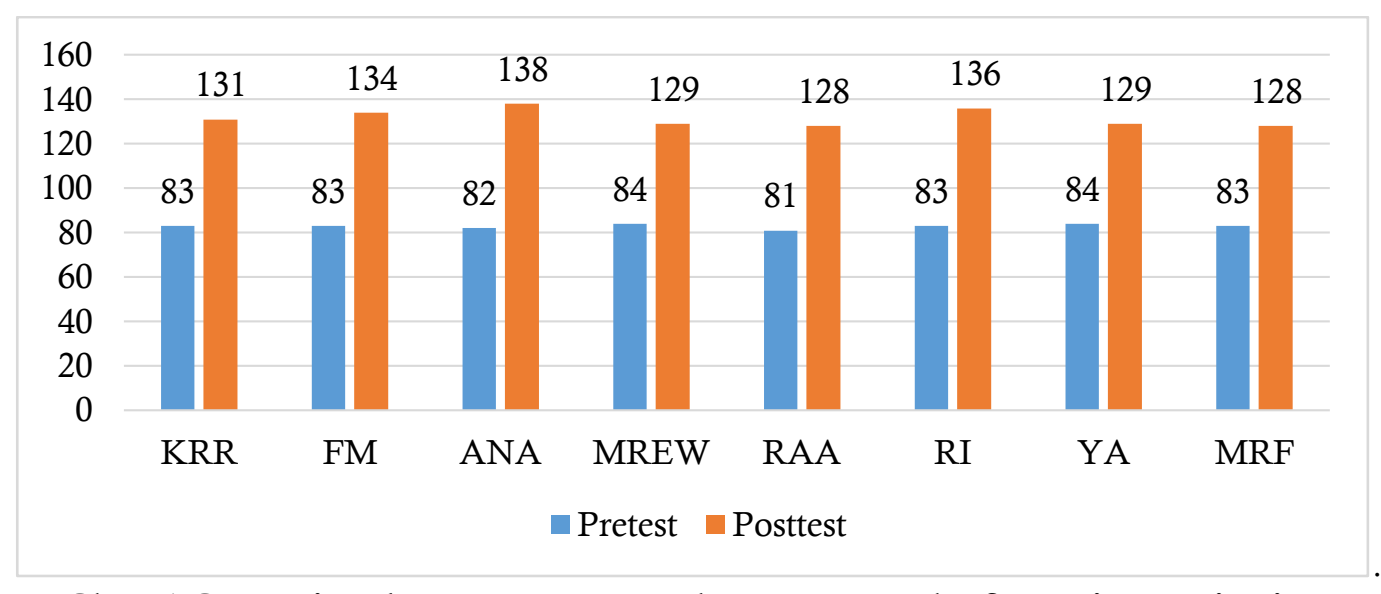

Chart 1 Comparison between Pre-test and Post-test Result of Learning Motivation

The analysis indicated a low initial learning motivation state with an average score of 83 . However, after being treatment with bibliocounseling, students' it improved to 131 .

The result of pre-test and post-test were then analyzed using the Wilcoxon test (Woolson, 2008) using IBM SPSS Statistics 25 as shown in table 1:

Table 1 Wilcoxon Testbetween Pre-test and Post-test Result of Learning Motivation

\section{Posttest- Pretest}

$\mathrm{Z}-2.533^{\mathrm{a}}$

Asymp. Sig. (2-tailed)

.011

Based on the calculationZ count and the significance (2-tailed) were 2.533 and 0.011 respectively. If the probability $<0,05$, Ho (Hypothesis null) is rejected and Ha (Alternative Hypothesis) is accepted. Therefore, when the Wilcoxon test shows a significance (2-tailed) of $0.011<0.05$, bibliocounseling is 
effective in enhancing the learning motivation of students of Class XI SMA, who become the subjects of the study, with an acceptable validity.

The pretest and posttest on all levels of students learning motivation experience is shown in figure1. Based on the treatment observation, several factors such as, group counseling service with bibliocounseling technique helped to enhance students skills..

The second factor is students' attractiveness using novels. This runs seamlessly, making it easier for new contents to be understand. The importance of attractiveness of a service or learning process is in luine with Mao, 2014who stated that students tend to enjoy learning presented with attractive materials. A new style and instrument are more appealing to them with lots of creativity (Barkley, Cross, \& Major, 2014).

Furthermore, based on observations, students find learning interesting when taught with short stories (Popa \& Porumbu, 2017). These students frequently said that the short stories were usually new one, thereby realizing their curiosity and interest levels. Providing delightful service is essential to draw students' interest (Rashid, 2015). It indirectly generates other factors affecting students' motivation, such as learning stimulus as well as dynamic factors in learning and affection (Iten \& Petko, 2016).

Based on the observation during the service, students seemed to be very passionate and exhibited good improvementusing bibliocounseling. Through reading, they may obtain insight and knowledge which could improve their learning motivation (Csorba-Simon, 2014). This study proves that bibliocounseling is likely to enhance students' learning motivation.

\section{Conclusions}

Based on the post-test results using eight students, learning motivation can be enhanced using bibliocounseling. Based on the result, several suggestions for the counselors and the researchers were made. These are as follows (1) Since this study found that bibliocounseling enhances class XI students' learning motivation, it can be suggested for school counselors to consider in implementing it into their strategies. It is expected to be able to improve the guidance and counseling service in students with lowlearning motivation. (2) For researchers, this study can be used as a reference, insight, and experience. (3), it still holds many deficiencies, however, a lot could still be probed.. It is expected that future studies will reinforce the present result.

\section{References}

Akinola, A. N. (2014). Bibliotherapy as an Alternative Approach to Children's Emotional Disorders. Creative Education, 5(14), 1281-1285.

Altunbay, M. (2018). Using Literature in Bibliotheraphy: Biography Sampling. Journal of Education and Training Studies, 6(11), 201-206.

Arulanantham, S., \& Navaneethakrishnan, S. (2014). Introducing Bibliotherapy in Public Libraries of Jaffna district: an Exploratory Study. Journal of the University Librarians Association of Sri Lanka, 17(2), $104-118$.

Barkley, E. F., Cross, K. P., \& Major, C. H. (2014). Collaborative learning techniques: A handbook for college faculty. New Jersey: John Wiley \& Sons.

Baumeister, R. F. (2016). Toward a general theory of motivation: Problems, challenges, opportunities, and the big picture. Motivation and Emotion, 40(1), 1-10.

Béres, J. (2015). Bibliotherapy \& Creative Writing for Talented Disadvantaged Youth. ProInflow: C̆asopis pro Informačni Vèdy, 7(2), 4-11.

Brophy, J. E. (2017). Fostering student learning and motivation in the elementary school classroom. In Learning and motivation in the classroom (pp. 283-306). London: Routledge.

Canty, N. (2017). Bibliotherapy. Logos, 28(3), 32-40.

Creswell, J. W., \& Creswell, J. D. (2017). Research Design: Qualitative, Quantitative, and Mixed Methods Approaches. Thousand Oaks, CA: Sage Publications.

Csorba-Simon, E. (2014). Bibliotherapy with prisoners? BOBCATSSS 2014 Proceedings, 1(1), 266-270. 
Davis, A. P., Wilcoxon, S. A., \& Townsend, K. M. (2017). Options and Considerations for Using Bibliotherapy in the School Setting. Alabama Counseling Association Journal, 41(2), 65-81.

Freeman, S., Eddy, S. L., McDonough, M., Smith, M. K., Okoroafor, N., Jordt, H., \& Wenderoth, M. P. (2014). Active learning increases student performance in science, engineering, and mathematics. Proceedings of the National Academy of Sciences, 111(23), 8410-8415.

Furner, J. M. (2017). Helping All Students Become Einstein's Using Bibliotherapy When Teaching Mathematics to Prepare Students for a STEM World. Pedagogical Research, 2(1), n1.

Gerlach, H., \& Subramanian, A. (2016). Qualitative analysis of bibliotherapy as a tool for adults who stutter and graduate students. Journal of Fluency Disorders, 47, 1-12.

Gupta, V. K., Mishra, R., \& Saini, P. K. (2017). Bibliotherapy: A therapeutic adjuvant in medicine. Gyankosh-The Journal of Library and Information Management, 8(1), 32-41.

Hester, R., \& Gore, J. S. (2015). Mechanisms that foster relational motivation. Psychological Studies, 60(1), 50-55.

I lbay, A. B. (2016). The Impact of Biblio group Counseling Supported with the Story of the Little Prince upon Mindfulness. Journal of Education and Training Studies, 4(6), 58-68.

Iten, N., \& Petko, D. (2016). Learning with serious games: Is fun playing the game a predictor of learning success? British Journal of Educational Technology, 47(1), 151-163.

Karacan, N., \& Güneri, O. Y. (2010). The effect of self-esteem enrichment bibliocounseling program on the self-esteem of sixth grade students. Procedia - Social and Behavioral Sciences, 5, 318-322. https://doi.org/10.1016/j.sbspro.2010.07.096

Karacan, N., \& Güneri, O. Y. (2010). The effect of self-esteem enrichment bibliocounseling program on the self-esteem of sixth grade students. Procedia - Social and Behavioral Sciences, 5, 318-322. https://doi.org/https://doi.org/10.1016/j.sbspro.2010.07.096

Kennedy, M. M. (2016). How does professional development improve teaching? Review of Educational Research, 86(4), 945-980.

Liu, R., \& Chiang, Y.-L. (2019). Who is more motivated to learn? The roles of family background and teacher-student interaction in motivating student learning. Journal of Chinese Sociology, 6(1). https://doi.org/10.1186/s40711-019-0095-z

Mao, J. (2014). Social media for learning: A mixed methods study on high school students' technology affordances and perspectives. Computers in Human Behavior, 33, 213-223.

McMillen, P. (2014). A therapeutic collaboration: The bibliotherapy education project at Oregon State University. OLA Quarterly, 12(2), 14-15.

Meier-Jensen, W. (2001). The effects of bibliotherapy on reducing stress/worry in inner-city first grade students. Master thesis, The University of Wisconsin, Stout. Retrieved March 20, 2008 ....

Nardi, P. M. (2018). Doing Survey Research: A Guide to Quantitative Rethods. London: Routledge.

Nicoll, W. G. (2014). Developing Transformative Schools: A Resilience-Focused Paradigm for Education. International Journal of Emotional Education, 6(1), 47-65.

Özdemir, N. K. (2016). An experimental study: The impact of bibliocounseling on self-esteem of sixth grade students . Elementary Education Online, 15(1), 136-147. https://doi.org/10.17051/io.2016.59570

Pardeck, J. A. (2014). Using books in clinical social work practice: A guide to bibliotherapy. London: Routledge.

Popa, D., \& Porumbu, D. (2017). Bibliotherapy in clinical context: an umbrella review. Transilvania University of Brasov. Series VII, Social Sciences, Law., 10(2), 165-174.

Rashid, M. (2015). counseling and support services for distance learners at Allama Iqbal open University Pakistan. VFAST Transactions on Education and Social Sciences, 6(1), 50-54.

Sarkar, S. (2019). Gratitude, conscience, and reciprocity: Models of supplier motivation when quality is non-contractible. European Journal of Operational Research, 277(2), 633-642. https://doi.org/10.1016/j.ejor.2019.02.047

Shem, M. (2016). Bibliotherapy as a Problem-Solving Skill of Counsellors and Teachers for Character and Skills Development in Ogun State, Nigeria. Journal of Education and Practice, 7(20), 18-22.

$\mathrm{Su}, \mathrm{C}$., \& Cheng, C. (2015). A mobile gamification learning system for improving the learning motivation and achievements. Journal of Computer Assisted Learning, 31(3), 268-286.

Undang-Undang No. 20. (2003). Sistem Pendidikan Nasional. Jakarta: Direktorat Pendidikan Menengah Umum.

Veilleux, J. C. (2019). Shifts in momentary motivation to quit smoking based on experimental context and 
perceptions of motivational instability. Addictive Behaviors, 96, 62-67. https://doi.org/10.1016/j.addbeh.2019.04.012

Wolff, M., Wagner, M. J., Poznanski, S., Schiller, J., \& Santen, S. (2015). Not another boring lecture: engaging learners with active learning techniques. The Journal of Emergency Medicine, 48(1), 85-93.

Woolson, R. F. (2008). Wilcoxon Signed- Rank Test. Wiley Encyclopedia of Clinical Trials.

Zeigler-Hill, V., Vrabel, J. K., Sauls, D., \& Lehtman, M. J. (2019). Integrating motivation into current conceptualizations of personality. Personality and Individual Differences, 147, 1-7. https://doi.org/10.1016/j.paid.2019.04.019 